\title{
In-Text Abbreviations
}

AEMM

AFTA

AMF

AMM

APEC

APT

ARF

ASA

ASEAN

ASEM

CMI

CLMV

CSCAP

EAEG

EAS

EEZ

EU

FPDA

FTA

GATT

IMF

ISIS
ASEAN Economic Ministers Meeting

ASEAN Free Trade Area

Asian Monetary Fund

ASEAN Ministerial Meeting

Asia-Pacific Economic Cooperation

ASEAN Plus Three

ASEAN Regional Forum

Association of Southeast Asia

The Association of Southeast Asian Nations

Asia Europe Meetings

Chiang Mai Initiative

Cambodia, Laos, Myanmar, Vietnam

Council for Security Cooperation in the Asia-Pacific

East Asia Economic Group

East Asia Summit

Exclusive Economic Zone

European Union

Five Powers Defence Arrangements

Free Trade Agreement

General Agreement on Tariffs and Trade

International Monetary Fund

Institute of Strategic and International Studies 
NAFTA North American Free Trade Agreement

PMC

Post-Ministerial Conference

PTA

Preferential Trading Agreement

SEANWFZ Southeast Asian Nuclear Weapons Free Zone

SEATO

Southeast Asia Treaty Organization

SLORC

State Law and Order Restoration Council

SOM

Senior Officials Meeting

TAC

Treaty of Amity and Cooperation

ZOPFAN

Zone of Peace, Freedom, and Neutrality 
[Re]Negotiating East and Southeast Asia 
